\title{
A Simple, Quantitative Method for Measuring Chemotaxis and Motility in Bacteria
}

\author{
By JUDiTh P. ARMITAGE, D. P. JOSEY AND D. G. SMITH \\ Department of Botany and Microbiology, University College London, \\ London WCI $E$ 6BT
}

(Received 27 April 1977)

\section{INTRODUCTION}

The response of bacteria to chemical changes in their environment has been much studied recently (for reviews see Adler, 1976, and Berg, 1975). The method of choice for quantitatively measuring chemotaxis has been an adaptation by Adler (1969) of a method used at the turn of the century by Pfeffer (I888), which measures, by viable plate counts, the number of bacteria moving into a capillary under a chemotactic stimulus. This method is slow, needing overnight incubation of the plated bacteria.

Here we describe a method which can be used to measure positive and negative chemotaxis in bacteria quickly and accurately. The method uses a Coulter counter to measure the percentage of a suspension of motile bacteria passing through a polycarbonate membrane in a given time, into a cell-free buffer, under a chemotactic influence.

This method can also be adapted for measuring the percentage of motile bacteria in a culture. This is achieved by comparing the number of bacteria passing through the membrane in a given time with standards of known percentage motility.

\section{METHODS}

Organisms and culture conditions. Strains of Escherichia coli, Streptococcus faecalis and Bacillus megaterium were isolated in this laboratory. Proteus mirabilis PI I was an isolate from University College Hospital.

Streptococcus faecalis was grown in a Bioflow $\mathrm{C}_{3}$ o chemostat (New Brunswick Scientific Co.) in conditions allowing $100 \%$ motility at $37^{\circ} \mathrm{C}$ in Brain Heart Infusion Broth (Oxoid). All other organisms were grown in Nutrient Broth no. 2 (Oxoid) to exponential phase at $30^{\circ} \mathrm{C}$ with shaking.

Chemotactic chambers. The blind well chemotactic chambers used in these experiments were obtained from Bio-Rad Laboratories. The upper and lower wells each had a capacity of $0.3 \mathrm{ml}$ and a polycarbonate membrane ( $13 \mathrm{~mm}$ diam.) was clamped between the two chambers.

Chemotaxis media. For chemotactic measurement, exponentially growing bacteria were resuspended in the chemotactic buffer of Adler (1973) which consists of 0.01 M-potassium phosphate buffer $\mathrm{pH} 7.0$ containing 0.1 mM-EDTA. Streptococcus faecalis was resuspended in 0.1 M-potassium phosphate buffer $\mathrm{pH} 7 \cdot \mathrm{I}$ containing $0.2 \mathrm{~g}$ glucose or pyruvate $\mathrm{I}^{-1}$ and I $\mathrm{g}$ Tween $80 \mathrm{l}^{-1}$ (Van der Drift et al., 1975).

Chemotaxis measurements. Chemotaxis in $S$. faecalis was measured by adding $0.3 \mathrm{ml}$ bacterial suspension in chemotactic buffer to the lower well of the chemotactic chamber. A Unipore membrane ( $2 \mu \mathrm{m}$ pore size, $13 \mathrm{~mm}$ diam.) was then fitted on top of the bottom well and the upper well was screwed on to it. The upper well was then filled with $0.3 \mathrm{ml}$ buffer containing the chemotactic agent. The percentage of the bacteria added to the lower well passing through the membrane was calculated by transferring $0.05 \mathrm{ml}$ after $90 \mathrm{~min}$ at $37^{\circ} \mathrm{C}$ to $10 \mathrm{ml}$ Isoton II and counting using a Coulter counter (Coulter Electronics, Dunstable, Bedfordshire).

The chemotactic responses of $E$. coli, $P$. mirabilis and $B$. megaterium were measured by pipetting $0.15 \mathrm{ml}$ bacterial suspension into the bottom well and $0.3 \mathrm{ml}$ buffer above the membrane ( $2 \mu \mathrm{m}$ pore size). The tops of the chambers were then sealed, avoiding air bubbles, with Parafilm (Gallenkamp) and the chambers were inverted. This prevents gas production interfering with the results, allows the environment to remain aerobic and stops bacteria being forced through the membrane by pressure when the membrane is screwed down. Samples $(0 . \mathrm{I} \mathrm{ml})$ were removed after $60 \mathrm{~min}$ at $30^{\circ} \mathrm{C}$ for counting as described above. 

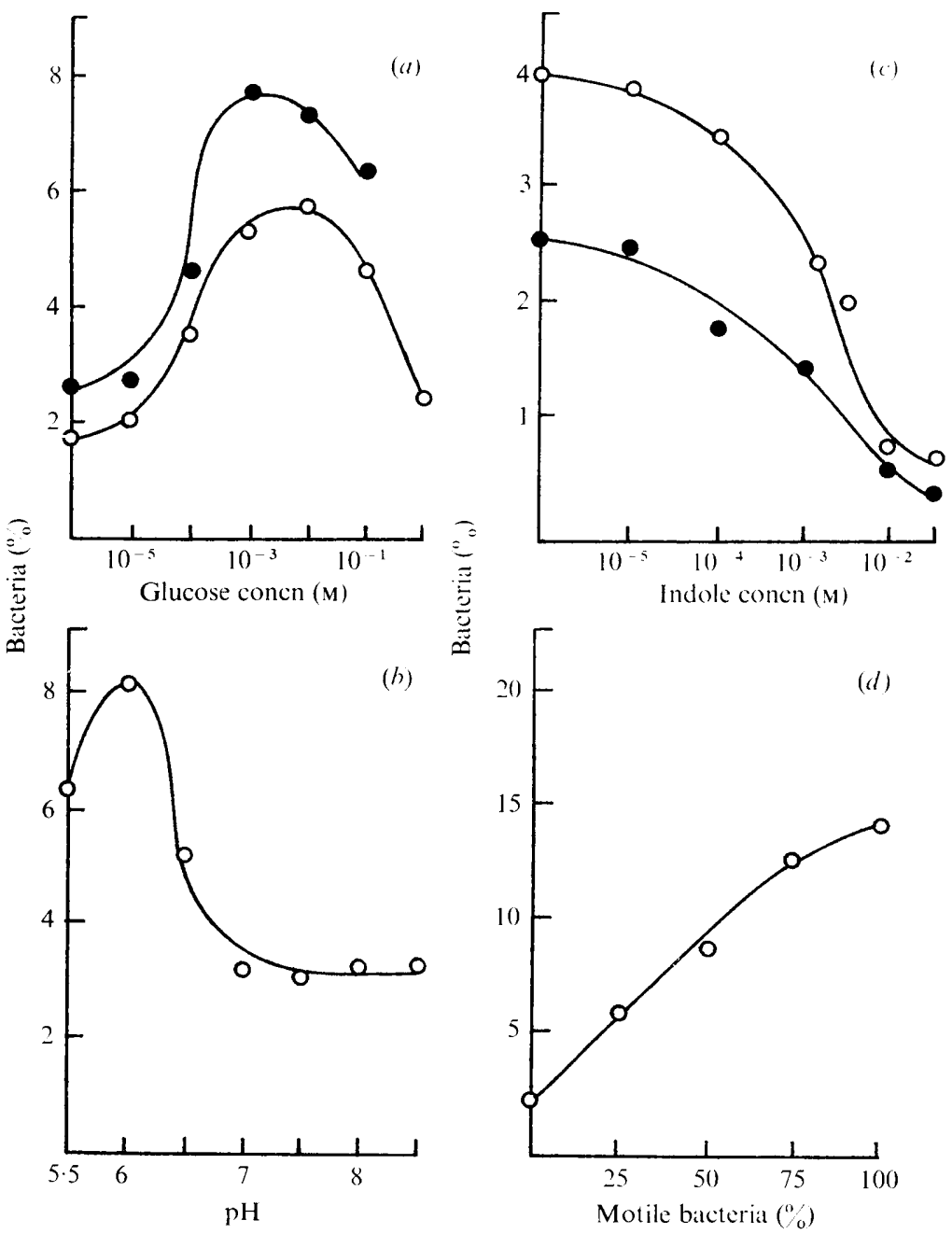

Fig. I. Chemotaxis and motility of bacteria measured by the percentage of bacteria passing through a polycarbonate membrane under various conditions. (a) Positive chemotaxis of $B$. megaterium $(\Theta)$ and $S$. faecalis $(\bigcirc)$ to glucose on the other side of the membrane. $(b)$ Negative chemotaxis of $E$. coli away from different $\mathrm{pH}$ buffers into cell-free neutral buffer. (c) Negative chemotaxis of $\boldsymbol{P}$. mirabilis $(\bigcirc)$ and $E$. coli $(O)$ away from indole dissolved in the cell-free buffer. (d) Percentage of $E$. coli passing through a membrane ( $5 \mu \mathrm{m}$ pore size) in $60 \mathrm{~min}$ as a function of the known percentage motility in a mixture of motile and non-motile bacteria.

Chemotaxis in all four species was measured either with a range of concentrations of the chemotactic agent in the top wells, or by mixing the bacteria with various concentrations of chemotactic agents and having blank buffer in the top well. In either case the percentage of the bacteria added to the bottom well passing into the top well was calculated.

Controls. For each bacterium the optimum bacterial density and time course had to be calculated as it appeared that at very high densities the bacteria interfered with each other and inhibited passage through the membranes; the optimum for each bacterium was about $5 \times 10^{8}$ bacteria $\mathrm{ml}^{-1}$, over 60 to $90 \mathrm{~min}$. The bacteria were examined microscopically after experiments to establish that motility had not been altered by the chemotactic agent.

Motility assay. This was achieved by adding a suspension of bacteria of known percentage motility to the bottom well and calculating the percentage passing through a membrane ( $5 \mu \mathrm{m}$ pore size) in $60 \mathrm{~min}$ at $30{ }^{\circ} \mathrm{C}$. The control percentage motility was achieved by mixing given amounts of $100 \%$ motile bacteria with a given amount of $100 \%$ non-motile (non-flagellate) bacteria. 


\section{RESULTS AND DISCUSSION}

\section{Chemotaxis}

This method was used successfully to show positive chemotaxis to a variety of sugars and amino acids in all four bacterial genera tested (Fig. I). When the attractant was placed in the upper well the percentage of bacteria passing through the membrane increased as the attractant concentration increased. The threshold concentration varied according to the bacterium and the attractant, for example the threshold of methionine attraction for $S$. faecalis was about $10^{-6} \mathrm{M}$, whereas the threshold of aspartate attraction for $E$. coli was about $1 \mathrm{O}^{-4} \mathrm{M}$. The saturation concentration for aspartate varied similarly, being $1 \mathrm{O}^{-3} \mathrm{M}$ with $S$. faecalis and $1^{-2} \mathrm{M}$ with $P$. mirabilis. When concentrations above the saturation concentration were used the percentage of bacteria passing through the membrane decreased. This presumably occurs when the gradient forming below the membrane in $60 \mathrm{~min}$ becomes greater than the saturation concentration. These results show a similar pattern to the positive chemotaxis response curve using the capillary method (Adler, 1973).

Negative chemotaxis was demonstrated in all four bacterial genera using this method (Fig. $\mathrm{I} b, c$ ). When cultures of $E$. coli were resuspended in buffers of different $\mathrm{pH}$ and cellfree buffer $(\mathrm{pH} 7)$ was added to the other side of the polycarbonate membrane there was an increase in the percentage of bacteria passing through the membrane at $\mathrm{pH}$ values below $\mathrm{pH} 7$ (the decrease at $\mathrm{pH} 5.5$ was probably due to reduced motility). Conversely, if the repellent was in the top well the percentage of bacteria passing through the membrane decreased as the concentration increased. As with the attractants, threshold and maximum concentrations could be measured. When repellents were tested the motility of the bacteria was always examined microscopically at the end of the experiment.

\section{Motility assay}

Some flagellate bacteria, for example $S$. faecalis, are only motile for a short period of their life cycle, and at any one time during growth in batch culture only a percentage will be motile. If chemotaxis is to be investigated in these organisms it is important that the percentage motility of the culture is known. This method has been used as a fast reliable assay for percentage motility using a large pore-size membrane $(5.0 \mu \mathrm{m})$ between the wells. Figure I $(d)$ shows a standard curve for $E$. coli. A volume of $100 \%$ motile bacteria grown in a chemostat was mixed with a volume of non-flagellate bacteria in chemotactic buffer to give a known percentage motility. The percentage of the bacteria added to the lower well passing through the membrane in $60 \mathrm{~min}$ at $30^{\circ} \mathrm{C}$ was calculated as in the chemotaxis assays and plotted against percentage motility. At densities of $5 \times 10^{8}$ bacteria $\mathrm{ml}^{-1}$ and below, the correlation was good up to $75 \%$ motility. Thereafter, whenever the percentage motility of a culture is needed it can be measured by reference to a standard curve for that organism at that bacterial density.

This method is a simple, reproducible and quick way of quantitatively measuring bacterial chemotaxis, and the percentage motility of a culture. The advantage over the capillary method is one of speed, the results of the experiments being available within hours rather than days, and accuracy, the number of bacteria being measured directly by a Coulter counter. The method is of general application in comparative studies of motile behaviour.

We wish to thank the Research Fund of the University of London for a grant to purchase the Bioflow chemostat. One of us (D.P.J.) also thanks the S.R.C. for financial support. 


\section{REFERENCES}

Adler, J. (1969). Chemoreceptors in bacteria. Pfeffer, W. (I888). Über chemotaktische BeweScience 166, $1588-1597$.

ADLER, J. (1973). A method for measuring chemotaxis and use of the method to determine optimum conditions for chemotaxis by Escherichia coli. Journal of General Microbiology 74, 77-9I.

Adler, J. (1976). Chemotaxis in bacteria. Annual Review of Biochemistry 44, 34I-356.

BERG, H. C. (1975). Chemotaxis in bacteria. Annual Review of Biophysics and Bioengineering 4, I19I 36. gungen von Bacterien, Flagellaten, und Volvocineen. Untersuchungen aus dem Botanischen Institut in Tubingen 2, 582-661.

Van der Drift, C., Duiverman, J., Bexkens, H. \& KRIJNEN, A. (1975). Chemotaxis of a motile Streptococcus towards sugars and amino acids. Journal of Bacteriology 124, I I42-I I 47. 